\title{
1 Epoxyalkenal-trapping ability of phenolic compounds
}

2 Rosario Zamora, Isabel Aguilar, and Francisco J. Hidalgo *

3 Instituto de la Grasa, Consejo Superior de Investigaciones Científicas, Carretera de

$4 \quad$ Utrera km 1, Campus Universitario - Edificio 46, 41013-Seville, Spain

5

$6 \quad *$ Corresponding author. Tel.: +34 954611 550; fax: +34 954616 790. E-mail

7 address: fhidalgo@ig.csic.es (F. J. Hidalgo)

8 


\section{ABSTRACT}

10 Lipid oxidation products have been shown to produce changes in food quality and 11 safety as a consequence of carbonyl-amine reactions. Some of these reactions can be 12 prevented by the use of phenolics, although the lipid-derived carbonyl trapping ability

13 of phenolics is still poorly understood. In an attempt to fill this gap, the reactions of 4,5-

14 epoxy-2-hexenal, 4,5-epoxy-2-heptenal, and 4,5-epoxy-2-decenal, with 2-

15 methylresorcinol and 2,5-dimethylresorcinol were studied. These reactions produced

16 diverse 1,3a,4,9b-tetrahydro-2H-furo[2,3-c]chromene-2,7-diols and 3,4,4a,9a-

17 tetrahydro-1H-pyrano[3,4-b]benzofuran-3,7-diols, which were isolated and

18 characterized by $1 \mathrm{D}$ and 2D nuclear magnetic resonance (NMR) and mass spectrometry

19 (MS). The produced epoxyalkenal-phenol reaction was characterized and carbonyl-

20 phenol adducts were produced firstly by epoxide-ring opening initiated by the attack of

21 one phenolic hydroxyl group and, then, by addition of one aromatic phenol carbon to

22 the carbon-carbon double bond of the epoxyalkenal. This reaction rapidly deactivated

23 the most important reactive groups of epoxyalkenals, decreasing in this way their ability

24 to modify amino compounds.

25 Keywords:

26 4,5-Epoxy-2-alkenals; Carbonyl-amine reactions; Carbonyl-phenol reactions; Lipid

27 oxidation; Maillard reaction; Reactive carbonyls

28 Chemical compounds studied in this article:

29 2,5-Dimethylresorcinol (PubChem ID: 24863551); 4,5-epoxy-2-heptenal (PubChem ID:

30 6444055); 4,5-epoxy-2-decenal (PubChem ID: 5352429); 2-methylresorcinol

31 (PubChem ID: 11843). 


\section{Introduction}

The oxidation of unsaturated fatty acyl chains is a major concern during food

processing or storage because of its consequences on quality and safety of foods, including both changes in flavor, texture, appearance, and nutritional quality, and the formation of potentially toxic compounds (Gramza-Michalowska, Kobus-Cisowska, Kmiecik, Korczak, Helak, Dziedzic, et al., 2016; Liu, Liu, Xue, \& Gao, 2016;

Sainsbury, Grypa, Ellingworth, Duodu, \& De Kock, 2016). Among the myriad of compounds produced as a consequence of the lipid oxidation in complex food systems, the formation toxic oxygenated unsaturated aldehydes has been the objective of numerous studies (Guillen \& Goicoechea, 2008; Guillen \& Uriarte, 2012). These compounds are highly reactive, and their ability to modify important food components has been thoroughly studied (Zamora \& Hidalgo, 2005; Hidalgo \& Zamora, 2016).

44 Nevertheless, some studies have suggested that these highly reactive lipid oxidation products can be trapped by phenolic compounds (Delgado, Hidalgo, \& Zamora, 2016; Hidalgo \& Zamora, 2014; Zhu, Zheng, Cheng, Wu, Zhang, Tang, et al, 2009), a reaction that would constitute an additional protective mechanism of phenolic compounds in food products (Zamora \& Hidalgo, 2016). Thus, some of these lipid-derived carbonyl compounds have been shown to be trapped by phenolic compounds in food products at the same time that they are being produced (Zamora, Aguilar, Granvogl, \& Hidalgo, 2016). In addition, other highly reactive lipid oxidation products, namely 4,5-epoxy-2alkenals, have been shown to be trapped by phenolic compounds with preference to other lipid oxidation products and this reaction is fast enough to prevent the production

54 of the competitive carbonyl-amine reactions (Hidalgo, Delgado, \& Zamora, 2017). 
by epoxyalkenals, epoxyalkenal-phenol reactions remains to be characterized. In an attempt to filling this gap, this study analyzes the reaction of 4,5-epoxy-2-alkenals and phenolic compounds by both isolating and identifying the produced compounds, and studying the reaction conditions that favors the formation of the corresponding carbonyl-phenol adducts.

\section{Materials and methods}

\subsection{Materials}

Three 4,5-epoxy-2-alkenals were employed in this study. They were 4,5-epoxy-2hexenal, 4,5-epoxy-2-heptenal, and 4,5-epoxy-2-dexenal, which were synthesized from the corresponding 2,4-alkadienals (2,4-hexadienal, 2,4-heptadienal, and 2,4-decadienal, respectively) by epoxidation with 3-chloroperoxybezoic acid (Zamora, Gallardo, \& Hidalgo, 2006).

As model phenolic compounds, only simple $m$-diphenols were employed, namely 2methylresorcinol and 2,5-dimethylresorcinol. These phenolic compounds were selected because carbonyl-phenol adducts are formed mainly with phenolic compounds having two hydroxyl groups at metha positions (Salazar, Arámbula-Villa, Hidalgo, \& Zamora, 2014), and simple $m$-diphenols are efficient epoxyalkenal-trapping agents (Hidalgo, Delgado, \& Zamora, 2017).

Alkadienals, phenolic compounds and all other chemicals employed in this study were purchased from Sigma-Aldrich (St. Louis, MO), Fluka (Buchs, Switzerland), or Merck (Darmstadt, Germany) and were either analytical grade or the highest available grade.

\subsection{Formation of carbonyl-phenol adducts in the reaction of epoxyalkenals and} phenolic compounds 
$81 \quad$ For analytical studies, a mixture of $30 \mu \mathrm{mol}$ of the phenolic compound $(170 \mu \mathrm{L}$ of a

$820.176 \mathrm{mM}$ solution in water), $40 \mu \mathrm{mol}$ of the epoxyalkenal ( $40 \mu \mathrm{L}$ of a $1 \mathrm{M}$ solution in

83 methanol), and $300 \mu \mathrm{L}$ of $0.3 \mathrm{M}$ buffer was heated at $100{ }^{\circ} \mathrm{C}$ for $30 \mathrm{~min}$ under nitrogen,

84 unless other conditions are indicated. At the end of the heating process, samples were

85 cooled at room temperature $\left(22^{\circ} \mathrm{C}\right)$ for $15 \mathrm{~min}, 1.2 \mathrm{~mL}$ of ethanol added, and taken to

86 dryness using a flow of nitrogen.

87 Dried samples were acetylated by adding $30 \mu \mathrm{L}$ of internal standard (a solution of

$8836.64 \mathrm{mg}$ of cis-3-nonen-1-ol in $5 \mathrm{~mL}$ of anhydrous pyridine), $1 \mathrm{~mL}$ of anhydrous

89 pyridine, and $500 \mu \mathrm{L}$ of acetic anhydride. Mixtures were left $20 \mathrm{~h}$ in the dark at room

90 temperature.

91 Acetylated samples were treated with $2 \mathrm{~mL}$ of water and $2 \mathrm{~mL}$ of chloroform, and

92 stirred for $10 \mathrm{~s}$. After phase separation, the aqueous layer was removed and discarded.

93 The organic layer was washed several times (usually three) with $2 \mathrm{~mL}$ of $5 \% \mathrm{HCl}$ until

94 the pyridine was removed. Finally, the organic layer was washed with $2 \mathrm{~mL}$ of water to

95 remove the $\mathrm{HCl}$. The resulting organic extracts were treated with sodium sulfate to

96 eliminate the remaining humidity and then studied by GC-MS.

97 For preparative studies, the reaction conditions were the same but the reaction was

98 carried out using $2.4 \mathrm{mmol}$ of phenolic compound, $3.4 \mathrm{mmol}$ of epoxyalkenal, and 24

$99 \mathrm{~mL}$ of $0.3 \mathrm{M}$ sodium phosphate buffer, $\mathrm{pH}$ 8. Acetylation of the heated and dried

100 mixtures was carried out with $80 \mathrm{~mL}$ of anhydrous pyridine and $40 \mathrm{~mL}$ of acetic

101 anhydride. Acetylated compounds were extracted with chloroform, and the pyridine was

102 removed as described above. The mixtures of acetylated compounds obtained were

103 fractionated by column chromatography on silica gel 60 (230-400 mesh; Macherey-

104 Nagel, Düren, Germany) using hexane:diethyl ether mixtures as eluent and the 
separation was controlled by gas chromatography coupled to mass spectrometry (GCMS). The following compounds were isolated and characterized (Fig. 1): epoxy-2-heptenal (2b). ${ }^{1} \mathrm{H}$ NMR $\left(\mathrm{CDCl}_{3}\right): \delta$ (ppm) 1.04t (3H, $\left.J=7.4 \mathrm{~Hz}, \mathrm{C}_{3} \mathrm{CH}_{2}\right)$,

$1101.65 q u\left(2 \mathrm{H}, J=7.4 \mathrm{~Hz}, \mathrm{CH}_{3} \underline{\mathrm{C}}_{2}\right), 2.02 \mathrm{~s}\left(3 \mathrm{H}, \mathrm{C}_{3} \mathrm{C} 6\right), 2.21 \mathrm{~m}$ and $2.29 \mathrm{~m}(2 \mathrm{H}, \mathrm{H} 1)$, 2.33s (3H, $\left.\mathrm{CH}_{3} \mathrm{CO}\right), 3.52 \mathrm{~m}(1 \mathrm{H}, \mathrm{H} 4)$, 3.89q,br (1H, $\left.J=7.5 \mathrm{~Hz}, \mathrm{H} 9 \mathrm{~b}\right), 4.65 \mathrm{t}(1 \mathrm{H}, J=9.3$ Hz, H3a), 6.07dd (1H, $J=2.7 \mathrm{~Hz}$ and $5.2 \mathrm{~Hz}, \mathrm{H} 2), 6.59 \mathrm{~d}(1 \mathrm{H}, J=8.0 \mathrm{~Hz}, \mathrm{H} 8)$, and 6.97d (1H, $J=8.0 \mathrm{~Hz}, \mathrm{H} 9) .{ }^{13} \mathrm{C} \mathrm{NMR}\left(\mathrm{CDCl}_{3}\right): \delta(\mathrm{ppm}) 9.19\left(\mathrm{CH}_{3} \mathrm{C} 6\right), 9.45$

114 ( $\left.\underline{\mathrm{CH}}_{3} \mathrm{CH}_{2} \mathrm{C} 4\right), 20.76$ (CH3 $\left.\mathrm{CO}\right), 26.22\left(\mathrm{CH}_{3} \underline{\mathrm{CH}}_{2} \mathrm{C} 4\right), 29.58$ (C1), 36.56 (C9b), 74.33 (C4), 82.31 (C3a), 92.17 (C2), 113.51 (C6), 114.39 (C8), 120.90 (C9), 125.77 (C9a), 149.71 (C7), 158.60 (C5a), 169.39 ( $\mathrm{CH}_{3} \underline{\mathrm{CO}}$ ). This compound suffered a dehydration when studied by GC-MS and was converted into 2-ethyl-8-methyl-4-(2-oxoethyl)-2H-

118 chromen-7-yl acetate (10a). MS, m/z (\%, ion structure): $274\left(19, \mathrm{M}^{+}\right), 232\left(33, \mathrm{M}^{+}-\right.$

$\left.119 \mathrm{CH}_{2} \mathrm{CO}\right), 204$ (15, 232 - ethene), 203 (100, $\left.232-\mathrm{CH}_{3} \mathrm{CH}_{2}\right), 189$ (11, $\left.204-\mathrm{CH}_{3}\right), 175$ (19, 204 - CHO), 174 (31, $204-\mathrm{HCHO})$ and 161 (13, $\left.204-\mathrm{CH}_{2} \mathrm{CHO}\right)$. acetate (9b) was also isolated in the reaction between 2-methylresorcinol (1a) and 4,5epoxy-2-heptenal (2b). This compound is a stereoisomer of compound 9a. ${ }^{1} \mathrm{H}$ NMR $\left(\mathrm{CDCl}_{3}\right): \delta(\mathrm{ppm}) 1.06 \mathrm{t}\left(3 \mathrm{H}, J=7.4 \mathrm{~Hz}, \mathrm{C}_{3} \mathrm{CH}_{2}\right), 1.64 q u\left(2 \mathrm{H}, J=7.4 \mathrm{~Hz}, \mathrm{CH}_{3} \underline{\mathrm{CH}}_{2}\right)$, 2.02s (3H, $\left.\underline{\mathrm{C}}_{3} \mathrm{C} 6\right), 1.95 \mathrm{~m}$ and 2.30m (2H, H1), 2.32s (3H, $\left.\mathrm{CH}_{3} \mathrm{CO}\right), 3.51 \mathrm{~m}(1 \mathrm{H}, \mathrm{H} 9 \mathrm{~b})$, 3.84dt (1H, $J=3.9 \mathrm{~Hz}, J=8.7 \mathrm{~Hz}, J=8.7 \mathrm{~Hz}, \mathrm{H} 4)$, 4.58t (1H, $J=9.3 \mathrm{~Hz}, \mathrm{H3a}), 6.15 \mathrm{dd}$

$127(1 \mathrm{H}, J=5.9 \mathrm{~Hz}$ and $8.5 \mathrm{~Hz}, \mathrm{H} 2), 6.55 \mathrm{~d}(1 \mathrm{H}, J=8.0 \mathrm{~Hz}, \mathrm{H} 8)$, and 6.96d $(1 \mathrm{H}, J=8.0 \mathrm{~Hz}$, 
113.39 (C6), 114.13 (C8), 121.30 (C9), 126.16 (C9a), 149.65 (C7), 159.16 (C5a),

$131169.35\left(\mathrm{CH}_{3} \underline{\mathrm{CO}}\right)$. This compound also suffered a dehydration when studied by GC-MS and was converted into 2-ethyl-8-methyl-4-(2-oxoethyl)-2H-chromen-7-yl acetate (10a). This last compound was identical to the compound produced in the deshydration

134 of compound 9a. MS, m/z (\%, ion structure): $274\left(19, \mathrm{M}^{+}\right), 232$ (33, $\left.\mathrm{M}^{+}-\mathrm{CH}_{2} \mathrm{CO}\right), 204$

135 (15, 232 - ethene), $203\left(100,232-\mathrm{CH}_{3} \mathrm{CH}_{2}\right), 189$ (11, $\left.204-\mathrm{CH}_{3}\right), 175$ (19, $204-$

$136 \mathrm{CHO}), 174$ (31, $204-\mathrm{HCHO})$, and 161 (13, $\left.204-\mathrm{CH}_{2} \mathrm{CHO}\right)$. acetate (9c) was isolated in the reaction between 2,5-dimethylresorcinol (1b) and 4,5epoxy-2-decenal (2c). ${ }^{1} \mathrm{H}$ NMR $\left(\mathrm{CDCl}_{3}\right): \delta(\mathrm{ppm})$ 0.89t (3H, $\left.J=6.8 \mathrm{~Hz}, \mathrm{C}_{3} \mathrm{CH}_{2}\right), 1.30$

$140 \mathrm{~m}\left(6 \mathrm{H}, \mathrm{CH}_{3} \underline{\mathrm{C}}_{2} \underline{\mathrm{C}}_{2} \mathrm{C}_{2}\right), 1.58 \mathrm{~m}\left(2 \mathrm{H}, \underline{\mathrm{C}}_{2} \mathrm{C} 4\right), 1.85 \mathrm{~m}$ and $2.36 \mathrm{~m}(2 \mathrm{H}, \mathrm{H} 1), 1.98 \mathrm{~s}(3 \mathrm{H}$, $\left.\mathrm{C}_{3} \mathrm{C} 6\right), 2.23 \mathrm{~s}$ (3H, $\left.\mathrm{CH}_{3} \mathrm{C} 9\right), 2.31 \mathrm{~s}\left(3 \mathrm{H}, \mathrm{CH}_{3} \mathrm{CO}\right), 3.42 \mathrm{~m}$ (1H, H9b), 3.95ddd (1H, $J=$ $1.3 \mathrm{~Hz}, J=4.4 \mathrm{~Hz}, J=5.6 \mathrm{~Hz}, \mathrm{H} 4), 4.54 \mathrm{t}(1 \mathrm{H}, J=8.9 \mathrm{~Hz}, \mathrm{H3a}), 6.16 \mathrm{dd}(1 \mathrm{H}, J=6.1 \mathrm{~Hz}$ and $9.1 \mathrm{~Hz}, \mathrm{H} 2)$, and 6.37s (1H, H8). ${ }^{13} \mathrm{C} \mathrm{NMR}\left(\mathrm{CDCl}_{3}\right): \delta(\mathrm{ppm}) 9.04\left(\underline{\left.\mathrm{CH}_{3} \mathrm{C} 6\right)}, 13.97\right.$

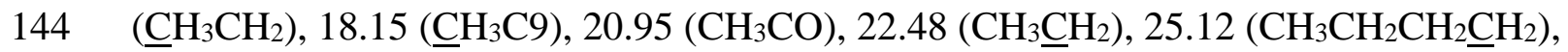
29.00 (C1), 29.74 (대글 4 ), 31.61 ( $\left.\mathrm{CH}_{3} \mathrm{CH}_{2} \underline{\mathrm{CH}}_{2}\right), 37.04$ (C9b), 71.85 (C4), 84.61 (C3a), 92.03 (C2), 110.49 (C6), 115.18 (C8), 124.63 (C9), 132.17 (C9a), 149.52 (C7), 159.03 (C5a), 169.45 ( $\left.\mathrm{CH}_{3} \underline{\mathrm{CO}}\right)$. This compound suffered a dehydration when studied by GCMS and was converted into 8-methyl-4-(2-oxoethyl)-2-pentyl-2H-chromen-7-yl acetate 149 (10c). MS, m/z (\%, ion structure): 330 (27, $\left.\mathrm{M}^{+}\right), 288$ (59, $\left.\mathrm{M}^{+}-\mathrm{CH}_{2} \mathrm{CO}\right), 273$ (5, 288 СH3), 259 (10, $\left.288-\mathrm{CH}_{3} \mathrm{CH}_{2}\right), 245$ (12, $\left.288-\mathrm{CH}_{3} \mathrm{CH}_{2} \mathrm{CH}_{2}\right), 218$ (15, 288 - pentene), 217 (100, $\left.288-\mathrm{CH}_{3} \mathrm{CH}_{2} \mathrm{CH}_{2} \mathrm{CH}_{2} \mathrm{CH}_{2}\right), 189$ (41, 218 - CHO), 188 (67, 218 - HCHO), 152175 (69, $\left.218-\mathrm{CH}_{2} \mathrm{CHO}\right)$, and 151 (84). 
155 hexenal (2a). ${ }^{1} \mathrm{H}$ NMR (CDCl3): $\delta(\mathrm{ppm}) 1.26 \mathrm{~d}\left(3 \mathrm{H}, J=6.6 \mathrm{~Hz}, \mathrm{CH}_{3} \mathrm{C} 1\right), 1.99 \mathrm{~s}(3 \mathrm{H}$, $\left.156 \mathrm{CH}_{3} \mathrm{C} 8\right), 2.08 \mathrm{~s}\left(3 \mathrm{H}, \mathrm{CH}_{3} \mathrm{CO}\right), 2.28 \mathrm{~m}(2 \mathrm{H}, \mathrm{H} 4), 2.32 \mathrm{~s}\left(3 \mathrm{H}, \mathrm{CH}_{3} \mathrm{CO}\right), 3.12 \mathrm{~d}(1 \mathrm{H}, J=3.9$ $157 \mathrm{~Hz}, \mathrm{H} 4 \mathrm{a}), 4.24 \mathrm{~d}(1 \mathrm{H}, J=7.8 \mathrm{~Hz}, \mathrm{H9a}), 4.79 \mathrm{dt}(1 \mathrm{H}, J=7.8 \mathrm{~Hz}, J=6.6 \mathrm{~Hz}, \mathrm{H} 1), 5.84 \mathrm{~d}$ $158(1 \mathrm{H}, J=3.2 \mathrm{~Hz}, \mathrm{H} 3), 6.57 \mathrm{~d}(1 \mathrm{H}, J=8.1 \mathrm{~Hz}, \mathrm{H} 6)$, and $6.85 \mathrm{~d}(1 \mathrm{H}, J=8.1 \mathrm{~Hz}, \mathrm{H} 5) .{ }^{13} \mathrm{C}$ 159

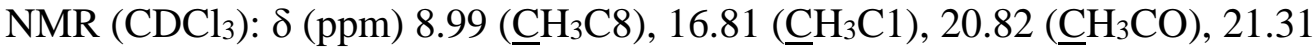
(태긍), 30.21 (C4), 37.57 (C4a), 69.77 (C1), 91.39 (C9a), 99.35 (C3), 113.77 (C6),

161

162

163

164

165

166

167

168

169

170

171

172

173

174

175

176

177

178

179 118.64 (C8), 123.50 (C5), 126.17 (C4b), 149.18 (C7), 150.59 (C8a), 169.35 (CH3드), and 170.31 (CH3드). MS, m/z (\%, ion structure): $320\left(8, \mathrm{M}^{+}\right), 278\left(1, \mathrm{M}^{+}-\mathrm{CH}_{2} \mathrm{CO}\right)$, 260 (8, $\left.278-\mathrm{H}_{2} \mathrm{O}\right), 245$ (43, $\left.260-\mathrm{CH}_{3}\right), 232$ (5, $\left.260-\mathrm{CO}\right), 218$ (38, $\left.260-\mathrm{CH}_{2} \mathrm{CO}\right)$, 203 (100, $\left.218-\mathrm{CH}_{3}\right), 190$ (50, $\left.218-\mathrm{CH}_{3} \mathrm{CH}\right), 176$ (9, $\left.218-\mathrm{CH}_{2} \mathrm{CO}\right), 175$ (43, $218-$ $\left.\mathrm{CH}_{3} \mathrm{CO}\right)$, and $161\left(66,176-\mathrm{CH}_{3}\right)$.

\section{1-Ethyl-8-methyl-3,4,4a,9a-tetrahydro-1H-pyrano[3,4-b]benzofuran-3,7-diyl}

diacetate (11b) was isolated in the reaction between 2-methylresorcinol (1a) and 4,5epoxy-2-heptenal (2b). ${ }^{1} \mathrm{H}$ NMR (CDCl3): $\delta$ (ppm) 0.91t (3H, $\left.J=7.4 \mathrm{~Hz}, \mathrm{C}_{3} \mathrm{CH}_{2}\right)$, $1.57 \mathrm{~m}$ and $1.78 \mathrm{~m}$ (2H, $\left.\mathrm{CH}_{2} \mathrm{C} 1\right)$, 1.99s (3H, $\left.\mathrm{CH}_{3} \mathrm{C} 8\right), 2.15 \mathrm{~s}\left(3 \mathrm{H}, \mathrm{CH}_{3} \mathrm{CO}\right), 2.29 \mathrm{~m}(2 \mathrm{H}$, H4), 2.32s (3H, СH3CO), 3.05d (1H, $J=3.9 \mathrm{~Hz}, \mathrm{H} 4 \mathrm{a}), 4.29 \mathrm{~d}(1 \mathrm{H}, J=8.3 \mathrm{~Hz}, \mathrm{H} 9 \mathrm{a})$, 4.75dt (1H, $J=3.8 \mathrm{~Hz}, J=8.1 \mathrm{~Hz}, \mathrm{H} 1), 5.83 \mathrm{~d}(1 \mathrm{H}, J=3.3 \mathrm{~Hz}, \mathrm{H} 3), 6.56 \mathrm{~d}(1 \mathrm{H}, J=8.1$ Hz, H6), and 6.83d (1H, $J=8.1 \mathrm{~Hz}, \mathrm{H} 5) .{ }^{13} \mathrm{C} \mathrm{NMR}\left(\mathrm{CDCl}_{3}\right): \delta(\mathrm{ppm}) 8.99(\underline{\mathrm{CH}} 3 \mathrm{C} 8)$,

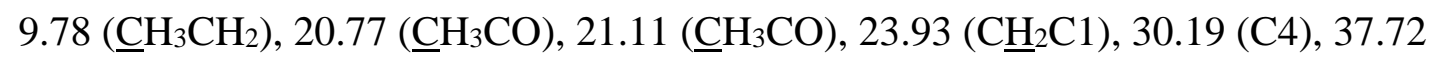
(C4a), 73.76 (C1), 89.85 (C9a), 99.34 (C3), 113.74 (C6), 118.61 (C8), 123.52 (C5), 126.15 (C4b), 149.18 (C7), 150.59 (C8a), 169.31 ( $\left.\mathrm{CH}_{3} \underline{\mathrm{CO}}\right)$, and 170.62 (CH3으). MS, m/z (\%, ion structure): 334 (4, $\left.\mathrm{M}^{+}\right), 292$ (1, $\left.\mathrm{M}^{+}-\mathrm{CH}_{2} \mathrm{CO}\right), 274$ (2, $\left.278-\mathrm{H}_{2} \mathrm{O}\right), 245$ (55, 274 - CHO), 232 (16, $\left.274-\mathrm{CH}_{2} \mathrm{CO}\right), 217$ (2, $\left.232-\mathrm{CH}_{3}\right), 203$ (100, $\left.232-\mathrm{CH}_{3} \mathrm{CH}_{2}\right)$, 191 (18, 232 - C3H5), 190 (5, 232 - CH2CO), 189 (15, 232 - $\left.\mathrm{CH}_{2} \mathrm{CHO}\right), 175$ (8, 190 $\left.\mathrm{CH}_{3}\right)$, and $161\left(39,190-\mathrm{CH}_{3} \mathrm{CH}_{2}\right)$. 
diacetate (11c) was also isolated in the reaction between 2-methylresorcinol (1a) and 4,5-epoxy-2-heptenal (2b). This compound is a stereoisomer of compound $\mathbf{1 1 b} .{ }^{1} \mathrm{H}$

NMR (CDCl3): $\delta$ (ppm) 0.85t (3H, $\left.J=7.5 \mathrm{~Hz}, \mathrm{CH}_{3} \mathrm{CH}_{2}\right), 1.65 \mathrm{~m}$ and $1.76 \mathrm{~m}(2 \mathrm{H}$,

$\left.\mathrm{CH}_{2} \mathrm{C} 1\right), 1.98 \mathrm{~s}\left(3 \mathrm{H}, \mathrm{CH}_{3} \mathrm{C} 8\right), 2.03 \mathrm{~s}\left(3 \mathrm{H}, \mathrm{CH}_{3} \mathrm{CO}\right), 2.25 \mathrm{dd}(2 \mathrm{H}, J=2.4 \mathrm{~Hz}, J=3.2 \mathrm{~Hz}$,

H4), 2.31s (3H, $\mathrm{CH}_{3} \mathrm{CO}$ ), 3.20dd (1H, $\left.J=3.0 \mathrm{~Hz}, J=5.1 \mathrm{~Hz}, \mathrm{H} 4 \mathrm{a}\right), 4.22 \mathrm{dd}(1 \mathrm{H}, J=3.2$

$\mathrm{Hz}, J=8.5 \mathrm{~Hz}, \mathrm{H} 9 \mathrm{a}), 4.47 \mathrm{ddd}(1 \mathrm{H}, J=4.1 \mathrm{~Hz}, J=6.5 \mathrm{~Hz}, J=8.5 \mathrm{~Hz}, \mathrm{H} 1), 5.80 \mathrm{br}(1 \mathrm{H}$, H3), 6.55d (1H, $J=8.1 \mathrm{~Hz}, \mathrm{H} 6)$, and 6.68d $(1 \mathrm{H}, J=8.1 \mathrm{~Hz}, \mathrm{H} 5) .{ }^{13} \mathrm{C} \mathrm{NMR}\left(\mathrm{CDCl}_{3}\right): \delta$

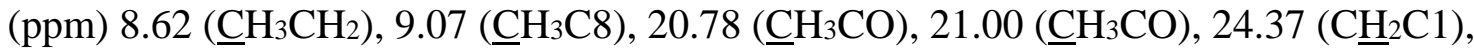
32.87 (C4), 38.40 (C4a), 73.94 (C1), 87.95 (C9a), 99.13 (C3), 113.75 (C6), 118.24

(C8), 122.00 (C4b), 125.11 (C5), 149.52 (C7), 150.15 (C8a), 169.30 (CHㅡㅡㅇ), and 169.61 (CH3으). MS, m/z (\%, ion structure): 334 (4, $\left.\mathrm{M}^{+}\right), 292$ (2, $\left.\mathrm{M}^{+}-\mathrm{CH}_{2} \mathrm{CO}\right), 274$ (3, $\left.278-\mathrm{H}_{2} \mathrm{O}\right), 245$ (18, $\left.274-\mathrm{CHO}\right), 232$ (28, $\left.274-\mathrm{CH}_{2} \mathrm{CO}\right), 217$ (1, $\left.232-\mathrm{CH}_{3}\right), 203$ (100, $\left.232-\mathrm{CH}_{3} \mathrm{CH}_{2}\right), 191$ (10, $\left.232-\mathrm{C}_{3} \mathrm{H}_{5}\right), 190$ (7, $\left.232-\mathrm{CH}_{2} \mathrm{CO}\right), 189$ (43, $232-$

$\left.\mathrm{CH}_{2} \mathrm{CHO}\right), 175$ (11, $\left.190-\mathrm{CH}_{3}\right)$, and $161\left(17,190-\mathrm{CH}_{3} \mathrm{CH}_{2}\right)$.

$\left.\mathrm{C}_{3} \mathrm{CH}_{2}\right), 1.48 \mathrm{~m}$ and $1.69 \mathrm{~m}\left(2 \mathrm{H}, \mathrm{CH}_{2} \mathrm{C} 1\right), 1.82 \mathrm{~s}\left(3 \mathrm{H}, \mathrm{CH}_{3} \mathrm{C} 8\right), 2.11 \mathrm{~s}\left(3 \mathrm{H}, \mathrm{CH}_{3} \mathrm{CO}\right)$,

2.19s (3H, $\left.\mathrm{CH}_{3} \mathrm{C} 5\right), 2.26 \mathrm{~m}$ (2H, H4), 2.27s (3H, $\left.\mathrm{CH}_{3} \mathrm{CO}\right), 3.31 \mathrm{~m}(1 \mathrm{H}, \mathrm{H} 4 \mathrm{a}), 4.07 \mathrm{~d}(1 \mathrm{H}$, $J=8.0 \mathrm{~Hz}, \mathrm{H} 9 \mathrm{a}), 4.68 \mathrm{dt}(1 \mathrm{H}, J=3.5 \mathrm{~Hz}, J=8.2 \mathrm{~Hz}, \mathrm{H} 1), 5.88 \mathrm{~d}(1 \mathrm{H}, J=3.2 \mathrm{~Hz}, \mathrm{H} 3)$,

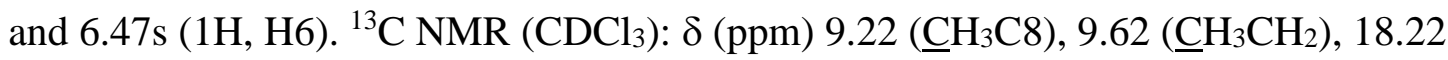

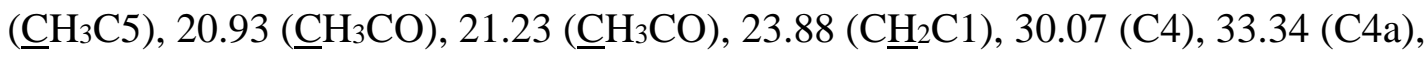
73.53 (C1), 89.92 (С9a), 99.27 (C3), 115.35 (C8), 115.74 (C6), 125.42 (C5), 131.76 
ion structure): $348\left(28, \mathrm{M}^{+}\right), 306\left(10, \mathrm{M}^{+}-\mathrm{CH}_{2} \mathrm{CO}\right), 288$ (1, $\left.292-\mathrm{H}_{2} \mathrm{O}\right), 259$ (53, 288 -

CHO), 246 (49, $\left.288-\mathrm{CH}_{2} \mathrm{CO}\right), 231$ (3, $\left.246-\mathrm{CH}_{3}\right), 217$ (100, $\left.246-\mathrm{CH}_{3} \mathrm{CH}_{2}\right), 205$ (35,

246 - $\left.\mathrm{C}_{3} \mathrm{H}_{5}\right), 204$ (14, 246 - $\left.\mathrm{CH}_{2} \mathrm{CO}\right), 203$ (75, 246 - $\left.\mathrm{CH}_{2} \mathrm{CHO}\right), 189$ (9, $\left.204-\mathrm{CH}_{3}\right)$,

176 (96, 204 - ethene), 175 (80, $\left.204-\mathrm{CH}_{3} \mathrm{CH}_{2}\right)$, and 161 (20, $\left.\mathrm{C}_{3} \mathrm{H}_{5}\right)$.

\subsection{GC-MS analyses}

GC-MS analyses were conducted with an Agilent 7820 gas chromatograph coupled with an Agilent 5977B mass selective detector (MSD), quadrupole type. The employed column was a fused-silica DB-5MS UI capillary column (30 m × 0.25 i.d.; coating thickness, $0.25 \mu \mathrm{m}$ ), and $1 \mu \mathrm{L}$ of sample was injected in the pulsed splitless mode. The

214 following working conditions were employed: carried gas, helium (0.8 $\mathrm{mL} / \mathrm{min})$;

215 injector, $250{ }^{\circ} \mathrm{C}$; oven temperature programmed from $100{ }^{\circ} \mathrm{C}(1 \mathrm{~min})$ to $300{ }^{\circ} \mathrm{C}$ at 15

$216{ }^{\circ} \mathrm{C} / \mathrm{min}$ and then $5 \mathrm{~min}$ at $300{ }^{\circ} \mathrm{C}$; transfer line to $\mathrm{MSD}, 280{ }^{\circ} \mathrm{C}$; ionization $\mathrm{EI}, 70 \mathrm{eV}$;

217 ion source temperature, $230{ }^{\circ} \mathrm{C}$; mass range 50-550 amu.

\subsection{Epoxyalkenal-phenol adduct determination}

219 The quantification of aldehyde-phenol adducts was carried out by preparing standard curves of the isolated adducts (9a, 9b, 11b, 11c) in the reaction between 4,5-epoxy-2heptenal and 2-methylresorcinol. For each curve, six different concentration levels of the adducts were used. Adduct content was directly proportional to the adduct/internal standard area ratio $(r>0.99, p<0.001)$. The coefficients of variation were $<10 \%$.

Because the reaction between 4,5-epoxy-2-heptenal and 2-methylresorcinol produced four isomers (Fig. S-1, Supplementary data) of 1-ethyl-8-methyl-3,4,4a,9a-tetrahydro$1 H$-pyrano[3,4-b]benzofuran-3,7-diyl diacetates (11) and only two of them could be isolated and employed for preparing the corresponding standard curves (11b and 11c), the quantification of the other two isomers $(\mathbf{1 1 e}, \mathbf{1 1 f})$ was carried out by employing a 
calibration curve that was the media of the other two. This approximation should be

230 considered satisfactory because the calibration curves of the adducts $\mathbf{1 1 b}$ and $\mathbf{1 1} \mathbf{c}$ were very similar between them.

\subsection{NMR Spectroscopy}

All NMR spectra were obtained using a Bruker Advance III spectrometer operating at $500 \mathrm{MHz}$ for protons. For ${ }^{1} \mathrm{H}$ and ${ }^{13} \mathrm{C}$ NMR spectra, acquisition parameters were described previously (Zamora, Aguilar, Granvogl, \& Hidalgo, 2016). All experiments were performed at $24{ }^{\circ} \mathrm{C}$ and COSY, HMQC and HMBC experiments were carried out to determine the chemical structures of the isolated compounds. Main HMBC couplings exhibited by compounds 9a and $\mathbf{1 1 b}$ are shown in Fig. S-2 (Supplementary data). HMBC couplings of compounds $\mathbf{9 b}$ and $\mathbf{9 c}$ were identical to those of compound $\mathbf{9 a}$. HMBC couplings of compounds 11a, 11c, and 11d were identical to those of compound $11 b$.

\subsection{Statistical analysis}

All data given are mean \pm SD values of, at least, three independent experiments.

244 Statistical comparisons among different groups were made using analysis of variance.

245 When significant $F$ values were obtained, group differences were evaluated by the

246 Tukey test (Snedecor \& Cochran, 1980). Statistical comparisons were carried out using 247 Origin ${ }^{\circledR}$ v. 7.0 (OriginLab Corporation, Northampton, MA). The significance level is $p$ $248<0.05$ unless otherwise indicated.

\section{Results} and phenolic compounds 
The reaction between epoxyalkenals and phenolic compounds is very fast and produces a complex mixture of compounds (Hidalgo, Delgado, \& Zamora, 2017).

254 Different attempts were carried out to isolate the produced compounds, but all of them

255

256

257 were unsuccessful because of the high reactivity of the formed adducts, which spontaneously suffered further reactions, including polymerizations. Only after their stabilization, they could be isolated and characterized. This stabilization was achieved by acetylation of the hydroxyl groups present in the formed molecules.

Two different kinds of adducts were isolated by column chromatography and characterized by 1D and 2D NMR and MS (Fig. 1). The first type of adducts were 1,3a,4,9b-tetrahydro-2H-furo[2,3-c]chromen-7-yl acetates (9). This cyclic form was the only observed in solution by NMR. However, because the hemiacetalic hydroxyl group was not acetylated, when studied by GC-MS, the cyclic hemiacetal was opened and the free hydroxyl group suffered a dehydration to produce the corresponding 4-(2oxoethyl)-2H-chromen-7-yl acetates (10).

Compounds 9 had only one acetyl group and two phenolic protons (or one in the case of compound 9c), indicating that one phenolic hydroxyl group and one of the phenolic protons of the original phenol were involved in the reaction with the epoxyalkenal. The epoxyalkenal chain could be easily identified in the adduct by means of a COSY experiment. The study of its chain showed that its epoxy, double bond and carbonyl groups were also involved in the reaction. The final characterization of their structures was carried out by using HMQC and HMBC experiments. In particular, HMBC showed long distance couplings, which were employed for the unequivocal identification of the formed structures.

Two isomers (9a,9b) were isolated in the reaction between 4,5-epoxy-2-heptenal and 2-methylresorcinol. This is consequence of the different chiral centers present in the 
molecule (C4, C3a, and C9b). Two of them (C3a and C4) corresponded to the epoxy

278 carbons of the epoxyalkenal (C4 and C5) and were already present in the aldehyde.

279 Because the initial alkadienal (2,4-heptadienal) was trans, trans and the epoxidation

280 was syn, the obtained epoxyalkenal should be a mixture of the isomer $4 R, 5 R$ and its

281 enantiomer. Supposing that the formation of the adduct did not imply a racemization,

282 the creation of the new chiral center at C9b would explain the existence of the two

283 isomers 9a and 9b. In addition, C2 is also chiral, although it is not fixed and the

284 interconversion between the two absolute configurations of this carbon might be

285 produced. The ${ }^{1} \mathrm{H}$ NMR spectra of both isomers were quite similar. The most significant

286 differences, as expected, corresponded to the protons belonging to chiral carbons C4,

287 C3a, C9b, and C2. One difference was the chemical shift of protons H4 and H9b, which

288 were interchanged in compounds $\mathbf{9 a}$ and $\mathbf{9 b}$ as confirmed by HMC experiments. Other

289 differences were the coupling constants, which were particularly different for H2. After

290 dehydration, both compounds produced the same compound 10a.

291 Differently to the reaction between 4,5-epoxy-2-heptenal and 2-methylresorcinol, in

292 the reaction between 4,5-epoxy-2-decenal and 2,5-dimethylresorcinol only one isomer

293 (9c) could be isolated and characterized. According to the chemical shifts of protons $\mathrm{H} 4$

294 and H9b, this compound was similar to compound 9b. However, isomer 9c differed

295 from isomer $\mathbf{9 b}$ in the coupling constants of H4, which were lower in compound 9c. On

296 the other hand, the mass spectrum of the dehydrated compound 10c was similar to the

297 mass spectra of compound 10a.

298 The second type of adducts produced in these reactions were 3,4,4a,9a-tetrahydro-

$2991 H$-pyrano[3,4-b]benzofuran-3,7-diyl diacetates (11). Compounds 11 had two acetyl

300 groups and two phenolic protons (or one in the case of compound 11d), indicating that,

301 at least, one of the phenolic protons of the original phenol was involved in the reaction 
302 with the epoxyalkenal. The epoxyalkenal chain could also be easily identified in the

303 adduct by means of a COSY experiment. The study of its chain showed that epoxy,

304 double bond and carbonyl groups of the epoxyalkenal were also involved in the

305 reaction. The final characterization of the structures was carried out by using HMQC

306 and HMBC experiments.

307 Analogously to the above described for compounds 9a and $\mathbf{9 b}$, the reaction between

308 4,5-epoxy-2-heptenal and 2-methylresorcinol produced several compounds 11. In this

309 case, four isomers were detected by GC-MS (Fig. S-2, Supplementary data), two of

310 which (11b and 11c) could be isolated and characterized. The existence of these 4

311 isomers is a consequence of the presence in the molecule of 4 chiral carbons: C1, C9a,

312 C4a, and C3. Two of them (C1 and C9a) were already present in the initial

313 epoxyalkenal, but C4a and C3 were created in the reaction with the phenol and C3 was

314 fixed in the later acetylation.

315 The ${ }^{1} \mathrm{H}$ NMR spectra of stereoisomers $\mathbf{1 1 b}$ and 11c were similar between them and

316 the main differences were again the chemical shifts and coupling constants of protons

317 close to chiral carbons. Thus, for example, the acetyl group of C3 was different for the

318 two isomers. On the other hand, the acetyl group of C7, which is quite far from the

319 chiral centers was identical for the two isomers. These differences were also observed in

320 the mass spectra. Thus, although the fragmentation pattern was identical for the two

321 isomers, the intensities of the produced fragments were different.

322 When the reaction was carried out between 4,5-epoxy-2-hexenal and 2-

323 methylresorcinol, only one isomer (11a) could be isolated and characterized. This

324 isomer was similar to compound $\mathbf{1 1 b}$ because it had similar coupling constants.

325 Something comparable occurred with compound 11d, which was isolated from the 
reaction between 4,5-epoxy-2-heptenal and 2,5-dimethylresorcinol. In addition, all compounds $\mathbf{1 1}$ had very similar fragmentation patterns by MS.

Although only a limited number of compounds could be isolated and characterized in the studied reactions, no other compounds having different mass fragmentation patterns were formed in the studied reactions to a significant extent. Therefore, it can be concluded that the reaction between epoxyalkenals and phenolic compounds mainly produces in a first step 1,3a,4,9b-tetrahydro-2H-furo[2,3-c]chromene-2,7-diols (7) and 3,4,4a,9a-tetrahydro-1H-pyrano[3,4-b]benzofuran-3,7-diols (8). These compounds have reactive hydroxyl and carbonyl groups that can be involved in further reactions, which is in agreement with the reactivity observed for the formed adducts.

\subsection{Effect of reaction conditions on the formation of epoxyalkenal-phenol adducts in} the reaction of 4,5-epoxy-2-heptenal and 2-methylresorcinol

The effect of reaction conditions on reaction between 4,5-epoxy-2-heptenal and 2methylresorcinol was studied to understand how this reaction is produced. A total ion chromatogram of the acetylated compounds formed in the reaction is shown in Fig. S-2

341 (Supplementary data). This reaction produced 1,3a,4,9b-tetrahydro-2H-furo[2,3-

342 c]chromene-2,7-diols (7) (which would produce compounds 9a or $\mathbf{9 b}$ after acetylation

343 and compound 10a after dehydration by GC-MS) and 3,4,4a,9a-tetrahydro- $1 \mathrm{H}$ -

344 pyrano[3,4-b]benzofuran-3,7-diols (8) (which would produce compounds 11b,11c,11e,11f after acetylation). Compounds 11e and 11f could not be isolated, but their mass spectra were very similar to those of compounds $\mathbf{1 1 b}$ and $\mathbf{1 1 c}$, therefore confirming that they were isomers of them. The 1,3a,4,9b-tetrahydro- $2 \mathrm{H}$-furo[2,3c]chromene-2,7-diol and the four 3,4,4a,9a-tetrahydro-1H-pyrano[3,4-b]benzofuran-3,7diols were the primary reaction products. However, they were unstable and spontaneously polymerized (the reaction developed brown color as a function of time, 
data not shown). To avoid further reactions of these compounds, reactions were stopped

352

353

354

355

356

357

358

359

360

361

362

363

364

365

366

367

368

369

370

371

372

373

374

by acetylation and studied by GC-MS.

Fig. 2 shows the effect of increasing amounts of 4,5-epoxy-2-heptenal on the disappearance of the phenolic compounds and the formation of epoxyalkenal-phenol adducts. The addition of increasing amounts of aldehyde produced the linear $(\mathrm{r}=-$ 0.996, $p=0.0003$ ) disappearance of the phenolic compound (Fig. 2A). The highest amount of epoxyalkenal tested ( $40 \mu \mathrm{mol})$ produced the disappearance of the $26 \%$ of the phenolic compound present (7.89 $\pm 1.38 \mu \mathrm{mol}$ of the phenol disappeared). This disappearance was parallel to the appearance of the adducts 10a and 11b, 11c, 11e, 11f. The amount of all of them increased linearly as a function of the amount of epoxyalkenal added and were inversely correlated $(r>0.98, p<0.003)$ to the disappearance of the phenol.

An analogous behavior was observed when increasing amounts of phenol were added (Fig. 3). Thus, the addition of increasing amounts of phenol produced the linear increase ( $r>0.98, p<0.002$ ) of the concentration of formed adducts 10a and 11b, 11c, 11e, 11f (Fig. 3B), therefore confirming that formation of adducts required the participation of both epoxyalkenal and phenolic compound.

Phenol disappearance and adduct formation were also pH-dependent (Fig. 4).

Adducts were not formed at $\mathrm{pH}<6$. However, the formation of some adducts $(\mathbf{1 0 a}, \mathbf{1 1 b}$, and 11c) was already significant at $\mathrm{pH} 7$, and the concentration of most of them increased at higher $\mathrm{pH}$ values. For most adducts, there were not significant differences between the amount formed at $\mathrm{pH} 8$ in the presence of either phosphate or borate, therefore confirming that it was the $\mathrm{pH}$ and not the employed buffer the responsible for the formation of these compounds. 

temperatures (Fig. 5). In general, phenol disappearance and adduct formation increased with time and temperature, although there were differences among the different adducts. Thus, adduct 10a was produced similarly at $60-100{ }^{\circ} \mathrm{C}$ but its concentration increased considerably at $120^{\circ} \mathrm{C}$ (Fig. 5B). At this temperature, its maximum concentration was achieved after only 20 min heating.

The concentration of adduct 11e exhibited a great dependence on the assayed temperature. Thus, the maximum concentration of this compound was obtained at low temperature because at temperatures higher than $80^{\circ} \mathrm{C}$ it suffered a significant decomposition (Fig. 5C).

Adducts 11b and 11c (Figs. 5E and 5D, respectively), exhibited a similar behavior among them as a function of time and temperature. Thus, they were produced to a similar extent at 80 and $100{ }^{\circ} \mathrm{C}$, but the amount at which they were produced decreased significantly $(p<0.5)$ at $60{ }^{\circ} \mathrm{C}$ and increased significantly $(p<0.5)$ at $120^{\circ} \mathrm{C}$.

389 Finally, the adduct 11 was the most temperature-dependent. It was almost not produced at $60{ }^{\circ} \mathrm{C}$ and its concentration increased considerably when heating temperature increased. Thus, adducts $\mathbf{1 0 a}, \mathbf{1 1} \mathbf{b}$, and $\mathbf{1 1 f}$ were the main products at 120 ${ }^{\circ} \mathrm{C}$. On the other and, adduct $\mathbf{1 1 f}$ was the adduct produced to a lower extent at $60{ }^{\circ} \mathrm{C}$.

\section{Discussion}

Epoxyalkenals are minor lipid oxidation products, but they react rapidly with amino acids, aminophospholipids and proteins producing their rapid degradation at the same time that non-enzymatic browning is produced by means of carbonyl-amine reactions

397 (Hidalgo \& Zamora, 1993). However, previous studies have pointed out that they are 
rapidly scavenged in the presence of certain phenolic compounds, which included single m-diphenols and flavan-3-ols (Hidalgo, Delgado, \& Zamora, 2017).

The above described results confirm that the reaction between phenolic compounds and epoxyalkenals takes place very rapidly and involves the three functional groups of the epoxyalkenal, which is an essential requirement to protect the amino compounds from degradation. However, although this reaction preserves amino compounds from degradations, the formed adducts still have some reactive groups that can produce further reactions. Therefore, the stabilization of these first reaction products was required for their isolation and characterization. This characterization showed that the first reaction products between epoxyalkenals and phenolics were 1,3a,4,9b-tetrahydro2H-furo[2,3-c]chromene-2,7-diols (7) and 3,4,4a,9a-tetrahydro-1H-pyrano[3,4b]benzofuran-3,7-diols (8).

Fig. 6 proposes a reaction pathway to explain the first steps of the reaction between phenols and epoxyalkenals and the formation of epoxyalkenal-phenol adducts. The reaction is initiated by the opening of the epoxy ring of the aldehyde (2) by one of the hydroxyl groups of the phenol (1). Two different compounds (3 and 4) are produced. Because of the disposition of the groups in the phenol, the aromatic carbon at the $\alpha$ position of the hydroxyl group has enough nucleophilia to be added to the carboncarbon double bond of compounds 3 and $\mathbf{4}$. These compounds are $\alpha, \beta$-unsaturated carbonyl compounds. Therefore, the addition of the aromatic carbon to the carboncarbon double bond occurs at the $\beta$-carbon. The result is the formation of a sixmembered ring in compound $\mathbf{5}$ when starting from compound $\mathbf{3}$, and a five-membered ring in compound $\mathbf{6}$ when starting from compound $\mathbf{4}$. Both adducts still have a carbonyl group and a hydroxyl group to an adequate distance to produce cyclic hemiacetals. Therefore, the predominant forms of these adducts are $1,3 \mathrm{a}, 4,9 \mathrm{~b}$-tetrahydro- $2 \mathrm{H}$ - 
423 furo[2,3-c]chromene-2,7-diol (7) and 3,4,4a,9a-tetrahydro-1H-pyrano[3,4-

424 b]benzofuran-3,7-diol (8), respectively. Upon acetylation under soft conditions,

425

426

427

428

429

430

431

432

433

434

435

436

437

438

439

440

441

442

443

444

445

446 compound $\mathbf{7}$ only suffers the acetylation of the phenolic hydroxyl group to produce adduct $\mathbf{9}$. However, the hydroxyl group of the six-membered ring of the hemiacetal $\mathbf{8}$ is acetylated at the same time that the phenolic hydroxyl group to produce adduct $\mathbf{1 1}$. This explains the concordance between NMR spectra and GC-MS spectra for adducts 11. On the other hand, when the acetylated compound $\mathbf{9}$ is submitted to GC-MS, the hemiacetal ring is opened and a dehydration is produced to form the corresponding 4-(2-oxoethyl)2H-chromen-7-yl acetate (10). This last compound was that observed by GC-MS.

Although only two products are formed in the first steps of these reactions, the reaction mixtures are quite complex because of the existence of different isomers (Fig. S-2, Supplementary data). According to the reaction pathway proposed in Fig. 6, the initial epoxyalkenal 2 is a mixture of $4 R, 5 R$ plus its enantiomer. These two carbons have different numberings depending on the produced compounds. Thus, they are $3 a R, 4 R$ plus its enantiomer if the numbering of compound 7 is employed or $9 \mathrm{a} R, 1 R$ plus its enantiomer if the numbering of compound $\mathbf{8}$ is used. The opening of the epoxide ring in compounds $\mathbf{3}$ and $\mathbf{4}$ implies the inversion of the stereochemistry of the carbon that suffers the attack of the phenolic hydroxyl group. As a result, compound $\mathbf{3}$ should be a mixture of $3 \mathrm{a} S, 4 R$ plus its enantiomer and compound $\mathbf{4}$ should be a mixture of $9 \mathrm{a} R, 1 S$ plus its enantiomer. The addition of the phenolic carbon to the carbon-carbon double bond creates a new chiral center. This means that compound 5 should be a mixture of $3 \mathrm{a} S, 4 R, 9 \mathrm{~b} R, 3 \mathrm{a} S, 4 R, 9 \mathrm{~b} S$ and their corresponding enantiomers. Something similar should be happening in compound $\mathbf{6}$, which should be a mixture of $1 S, 4 \mathrm{a} R, 9 \mathrm{a} R, 1 S, 4 \mathrm{a} S, 9 \mathrm{a} R$, and their corresponding enantiomers. 
Acetylation does not change the stereochemistry of compound 7, in which the stereochemistry of C2 is not fixed, and the later dehydration implies the loss of two chiral centers (C3a and C9b), and the formation of a carbon-carbon double bond with a fixed stereochemistry because of the six-membered ring. For that reason, compound $\mathbf{1 0}$ has only one chiral center, and only one dehydrated compound is observed in the gas chromatogram of Fig. S-2 (Supplementary data).

On the other hand, acetylation of compound $\mathbf{8}$ fixes a new chiral center (C3). This means that compounds 11 should be a mixture of $1 S, 3 R, 4 \mathrm{a} R, 9 \mathrm{a} R, 1 S, 3 S, 4 \mathrm{a} R, 9 \mathrm{a} R$, $1 S, 3 R, 4 \mathrm{a} S, 9 \mathrm{a} R, 1 S, 3 S, 4 \mathrm{a} S, 9 \mathrm{a} R$, and their corresponding enantiomers. For that reason, the gas chromatogram of Fig. S-2 (Supplementary data) shows the existence of four peaks with the same mass spectra that correspond to compounds $\mathbf{1 1 b}, \mathbf{1 1 c}, \mathbf{1 1 e}$, and 11f. Obviously, not all isomers have to be formed to the same extent, and those having less steric hindrance would be preferred. Thus, compound $\mathbf{1 1 b}$ was the 3,4,4a,9a-tetrahydro$1 H$-pyrano[3,4-b]benzofuran-3,7-diol formed to a higher extent in the reaction between 4,5-epoxy-2-alkenal and 2-methylresorcinol at the different assayed temperatures (Fig. $5)$.

The presence of hydroxyl and carbonyl groups in compounds $\mathbf{5}$ and $\mathbf{6}$ also explain the reactivity of these molecules and, therefore, the difficulty for their study. Saturated carbonyl compounds have been shown to react with phenolic compounds (see, for example, Totlani \& Peterson, 2005) and also with amino compounds (Kitryte, Adams, Venskutonis, \& De Kimpe, 2012), but their reactivity is much reduced in comparison to 468 that of epoxyalkenals (see, for example, Hidalgo, Delgado, Navarro, \& Zamora, 2010).

469 Therefore, phenolic compounds are able to reduce rapidly the high reactivity of 470 epoxyalkenals, although the produced adducts still have functional groups having a potential reactivity with both phenolics and amino compounds. 
Reaction pathway proposed in Fig. 6 is also in agreement with the effects of reaction conditions on adduct formation described previously. Thus, both epoxyalkenal (Fig. 2) and phenol (Fig. 3) take part in the reaction; the basic pH (Fig. 4) is needed for the addition of the aromatic carbon to the carbon-carbon double bond, as observed previously for 2-alkenals (Hidalgo \& Zamora, 2014); and reaction times and temperatures are expected to favor the formation of adducts. However, many steps in

478 Fig. 6 are reversible and the relative proportions among final products will change as a function of reaction conditions.

All obtained results contribute to a better understanding of the carbonyl-trapping ability of phenolic compounds in which both hydroxyl groups and phenolic carbons are involved. Thus, for saturated aldehydes, only the addition of phenolic aromatic carbons to the aldehydic carbonyl carbon has been described (Shao, Bai, He, Ho, Yang, \& Sang, 484 2008). However, in the case of 2-alkenals, the reaction can be initiated by addition of 485 either the phenolic hydroxyl group or the phenolic aromatic carbon to the carbon-carbon double bond of the aldehyde (Hidalgo \& Zamora, 2014). Nevertheless, in the case of epoxyalkenals, the reaction is always initiated by the epoxide-ring opening produced by the phenolic hydroxyl group and then the later addition of the phenolic aromatic carbon to the carbon-carbon double bond of the initial aldehyde. These results suggest a versatility of phenolic compounds, which are able to react differently with the diverse carbonyl compounds as a function of their structure. This provides an additional explanation of the differences observed in the scavenging of carbonyl compounds by 493 phenolic compounds, which depends on the structures of both the lipid-derived carbonyl 494 compounds and the phenolic compounds involved (Hidalgo, Delgado, \& Zamora, 2017).

\section{Conflict of interest}


497 The authors declare no conflicts of interest.

498 Acknowledgments

499 We are indebted to José L. Navarro for technical assistance. This study was

500 supported in part by the European Union (FEDER funds) and the Plan Nacional de I +

501 D of the Ministerio de Economía y Competitividad of Spain (project AGL2015-68186-

$502 \mathrm{R})$.

503 Appendix A. Supplementary data

504 Supplementary data associated with this article can be found, in the online version, at 
506 Delgado, R. M.; Hidalgo, F. J., \& Zamora, R. (2016). Antagonism between lipid507 derived reactive carbonyls and phenolic compounds in the Strecker degradation of 508 amino acids. Food Chemistry, 194, 1143-1148.

509 Gramza-Michalowska, A., Kobus-Cisowska, J., Kmiecik, D., Korczak, J., Helak, B., 510 Dziedzic, K., \& Gorecka, D. (2016). Antioxidative potential, nutritional value and 511 sensory profiles of confectionery fortified with green and yellow tea leaves (Calleia sinensis). Food Chemistry, 211, 448-454.

513 Guillen, M. D., \& Goicoechea, E. (2008). Formation of oxygenated alpha,beta-

514 unsaturated aldehydes and other toxic compounds in sunflower oil oxidation at room 515 temperature in closed receptacles. Food Chemistry, 111, 157-164.

516 Guillen, M. D., \& Uriarte, P. S. (2012). Aldehydes contained in edible oils of a very

517 different nature after prolonged heating at frying temperature: Presence of toxic oxygenated alpha,beta unsaturated aldehydes. Food Chemistry, 131, 915-926.

Hidalgo, F. J., \& Zamora, R. (1993). Fluorescent pyrrole products from carbonyl-amine reactions. Journal of the Biological Chemistry, 268, 16190-16197.

Hidalgo, F. J., \& Zamora, R. (2014). 2-Alkenal-scavenging ability of m-diphenols. Food Chemistry, 160, 118-126.

Hidalgo, F. J., \& Zamora, R. (2016). Amino acid degradations produced by lipid oxidation products. Critical Reviews in Food Science and Nutrition, 56, 1242-1252.

525 Hidalgo, F. J., Delgado, R. M., \& Zamora, R. (2017). Protective effect of phenolic 526 compounds on carbonyl-amine reactions produced by lipid-derived reactive 527 carbonyls. Food Chemistry, 229, 388-395. 
Hidalgo, F. J., Delgado, R. M., Navarro, J. L., \& Zamora, R. (2010). Asparagine decarboxylation by lipid oxidation products in model systems. Journal of Agricultural and Food Chemistry, 58, 10512-10517.

Kitryte, V., Adams, A., Venskutonis, P. R., \& De Kimpe, N. (2012). Impact of lipid oxidation-derived aldehydes and ascorbic acid on the antioxidant activity of model melanoidins. Food Chemistry, 135, 1273-1283.

Liu, S., Liu, F. G., Xue, Y. H., \& Gao, Y. X. (2016). Evaluation on oxidative stability of walnut beverage emulsions. Food Chemistry, 203, 409-416.

Sainsbury, J., Grypa, R., Ellingworth, J., Duodu, K. G., \& De Kock, H. L. (2016). The effects of antioxidants and shelf life conditions on oxidation markers in a sunflower oil salad dressing emulsion (SOSDE). Food Chemistry, 213, 230-237.

Salazar, R., Arámbula-Villa, G., Hidalgo, F. J., \& Zamora, R. (2014). Structural characteristics that determine the inhibitory role of phenolic compounds on 2-amino1-methyl-6-phenylimidazo[4,5-b]pyridine (PhIP) formation. Food Chemistry, 151, 480-486.

Shao, X., Bai, N., He, K., Ho, C.-T., Yang, C. S., \& Sang, S. (2008). Apple polyphenols, phloretin and phloridzin: New trapping agents of reactive dicarbonyl species. Chemical Research in Toxicology, 21, 2042-2050.

Snedecor, G. W., \& Cochran, W. G. (1980). Statistical Methods ( $7^{\text {th }}$ ed.). Ames, IA: Iowa State University Press.

Totlani, V. M., \& Peterson, D. G. (2005). Reactivity of epicatechin in aqueous glycine and glucose Maillard reaction models: Quenching of C2, C3, and C4 sugar fragments. Journal of Agricultural and Food Chemistry, 53, 4130-4135. 
551 Zamora, R., \& Hidalgo, F. J. (2005). Coordinate contribution of lipid oxidation and

552 Maillard reaction to the nonenzymatic food browning. Critical Reviews in Food

$553 \quad$ Science and Nutrition, 45, 49-59.

554 Zamora, R., \& Hidalgo, F. J. (2016). The triple defensive barrier of phenolic

555 compounds against the lipid oxidation-induced damage in food products. Trends in

$556 \quad$ Food Science \& Technology, 54, 165-174.

557 Zamora, R., Aguilar, I., Granvogl, M., \& Hidalgo, F. J. (2016). Toxicologically relevant

558 aldehydes produced during the frying process are trapped by food phenolics. Journal

559 of Agricultural and Food Chemistry, 64, 5583-5589.

560 Zamora, R., Gallardo, E., \& Hidalgo, F. J. (2006). Amine degradation by 4,5-epoxy-2-

561 decenal in model systems. Journal of Agricultural and Food Chemistry, 61, 10231-

$562 \quad 10237$.

563 Zhu, Q., Zheng, Z.-P., Cheng, K.-W., Wu, J.-J., Zhang, S., Tang, Y. S., Sze, K. H.,

564 Chen, J., \& Wang, M. (2009). Natural polyphenols as direct trapping agents of lipid

565 peroxidation-derived acrolein and 4-hydroxy-trans-2-nonenal. Chemical Research in

566 Toxicology, 22, 1721-1727.

567 


\section{Figure legends}

Fig. 1. Compounds isolated and characterized in the reaction of epoxyalkenals and simple phenolics.

Fig. 2. Effect of epoxyalkenal concentration on: A, phenol disappearance; and B, formation of carbonyl-phenol adducts. Reactions were carried out by heating a mixture of 4,5-epoxy-2-heptenal and 2-methylresorcinol (30 $\mu \mathrm{mol}, \nabla$ ) for $30 \mathrm{~min}$ at $100^{\circ} \mathrm{C}$ in the presence of $0.3 \mathrm{mM}$ sodium phosphate buffer. The carbonyl-phenol adducts produced were compounds $10 \mathrm{a}(\square), \mathbf{1 1 b}(\nabla)$, 11c $(\triangle)$, 11e $(\bigcirc)$, and $11 \mathbf{f}(\diamond)$.

Fig. 3. Effect of phenol concentration on: A, remaining phenol; and B, formation of carbonyl-phenol adducts. Reactions were carried out heating a mixture of 4,5-epoxy-2heptenal $(40 \mu \mathrm{mol})$ and 2-methylresorcinol $(\triangleright)$ for $30 \mathrm{~min}$ at $100{ }^{\circ} \mathrm{C}$ in the presence of $0.3 \mathrm{mM}$ sodium phosphate buffer. The carbonyl-phenol adducts produced were compounds 10a $(\square), 11 \mathrm{~b}(\nabla)$, 11c $(\triangle)$, 11e $(\bigcirc)$, and 11f $(\diamond)$.

Fig. 4. Effect of reaction $\mathrm{pH}$ on: $\mathrm{A}$, phenol disappearance; and $\mathrm{B}$, formation of carbonyl-phenol adducts. Reactions were carried out heating a mixture of 4,5-epoxy-2heptenal $(40 \mu \mathrm{mol})$ and 2-methylresorcinol $(30 \mu \mathrm{mol}, \triangleright)$ for $30 \mathrm{~min}$ at $100{ }^{\circ} \mathrm{C}$. The carbonyl-phenol adducts produced were compounds 10a $(\square), 11 \mathbf{b}(\nabla), 11 \mathbf{c}(\triangle), 11 \mathbf{e}$ $(\bigcirc)$, and 11f $(\diamond)$. Two buffers were employed: $0.3 \mathrm{M}$ sodium phosphate buffer (open symbols) and $0.3 \mathrm{M}$ sodium borate buffer (closed symbols).

Fig. 5. Effect of reaction time and temperature on: A, phenol disappearance; B, formation of compound 10a; C, formation of compound 11e; D, formation of compound 11c; E, formation of compound 11b; and F, formation of compound 11f. Reactions were carried out heating a mixture of 4,5-epoxy-2-heptenal $(40 \mu \mathrm{mol})$ and 2-methylresorcinol 
(30 $\mu \mathrm{mol}$ ) in $0.3 \mathrm{mM}$ sodium phosphate buffer at the indicated times and temperatures. The assayed temperatures were: $120(\square), 100(\bigcirc), 80(\triangle)$, and $60{ }^{\circ} \mathrm{C}(\nabla)$.

Fig. 6. Proposed reaction pathway for the reaction between epoxyalkenals and phenolic compounds. R and R' are $\mathrm{H}$ or alkyl groups. The assayed epoxyalkenals and phenolic compounds were: 2-methylresorcinol (1a, $\mathrm{R}=\mathrm{H})$, 2,5-dimethylresorcinol $(\mathbf{1 b}, \mathrm{R}=$ $\mathrm{CH}_{3}$ ), 4,5-epoxy-2-hexenal (2a, R' = $\mathrm{CH}_{3}$ ), 4,5-epoxy-2-heptenal (2b, R' = $\mathrm{CH}_{2} \mathrm{CH}_{3}$ ), and 4,5-epoxy-2-decenal (2c, $\left.\mathrm{R}^{\prime}=\mathrm{CH}_{2} \mathrm{CH}_{2} \mathrm{CH}_{2} \mathrm{CH}_{2} \mathrm{CH}_{3}\right)$. 
<smiles></smiles>

$9 a, 9 b$

$10 a$<smiles>CCCCCC1C=C(CC=O)c2c(C)cc(OC(C)=O)c(C)c2O1</smiles>

10c

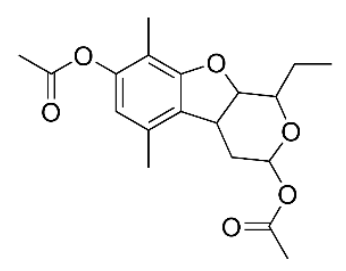

11d

Figure 1 


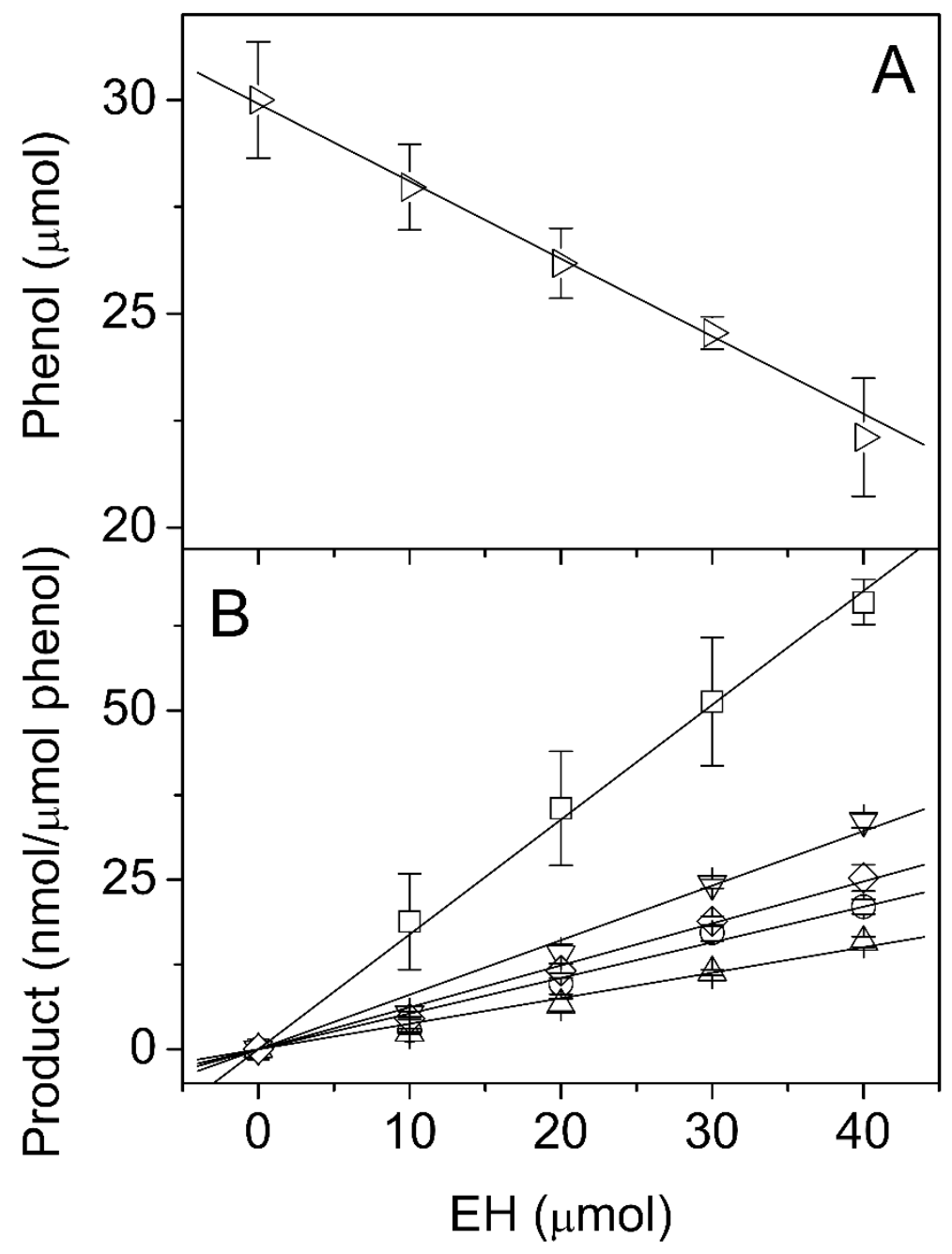

Figure 2 


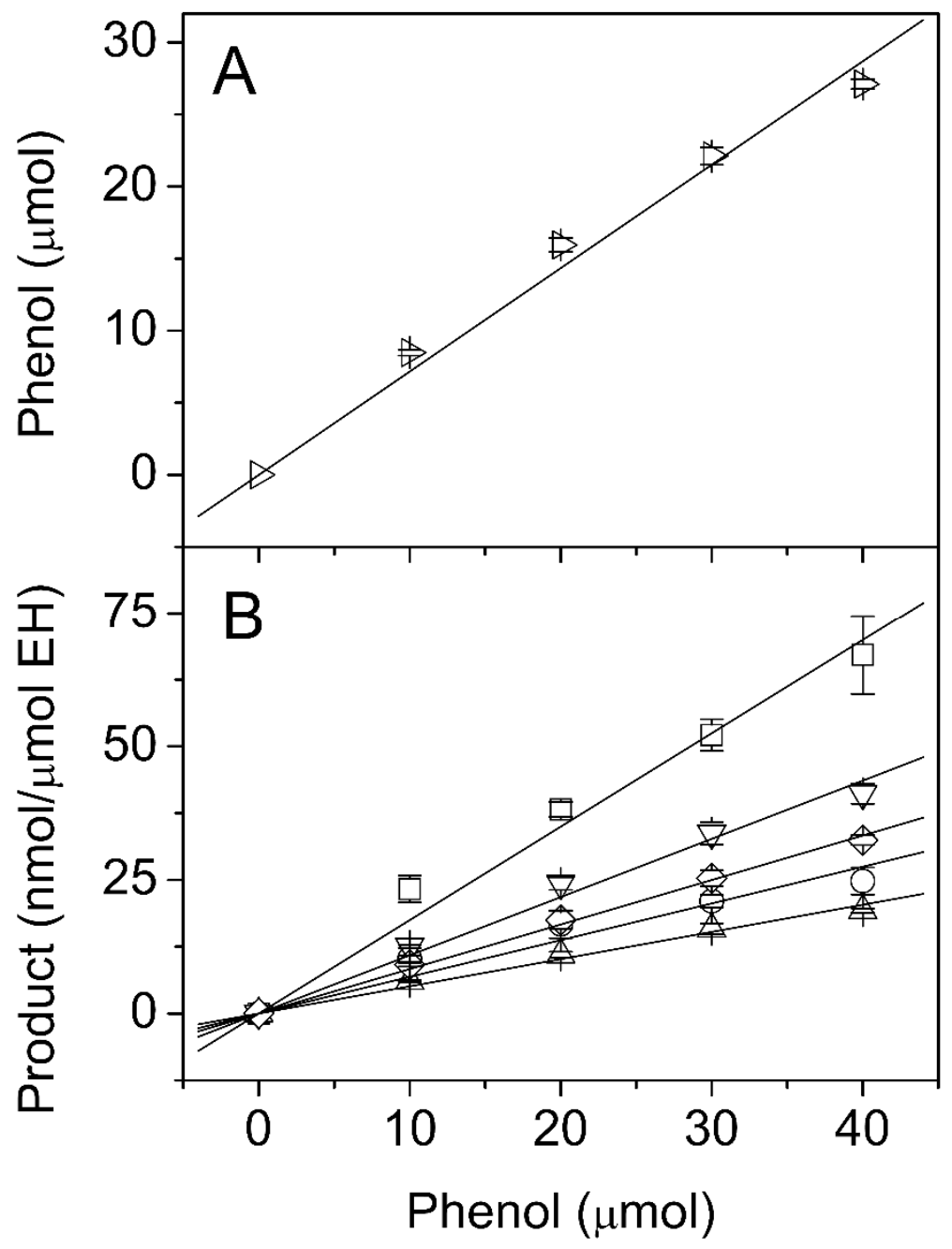

Figure 3 


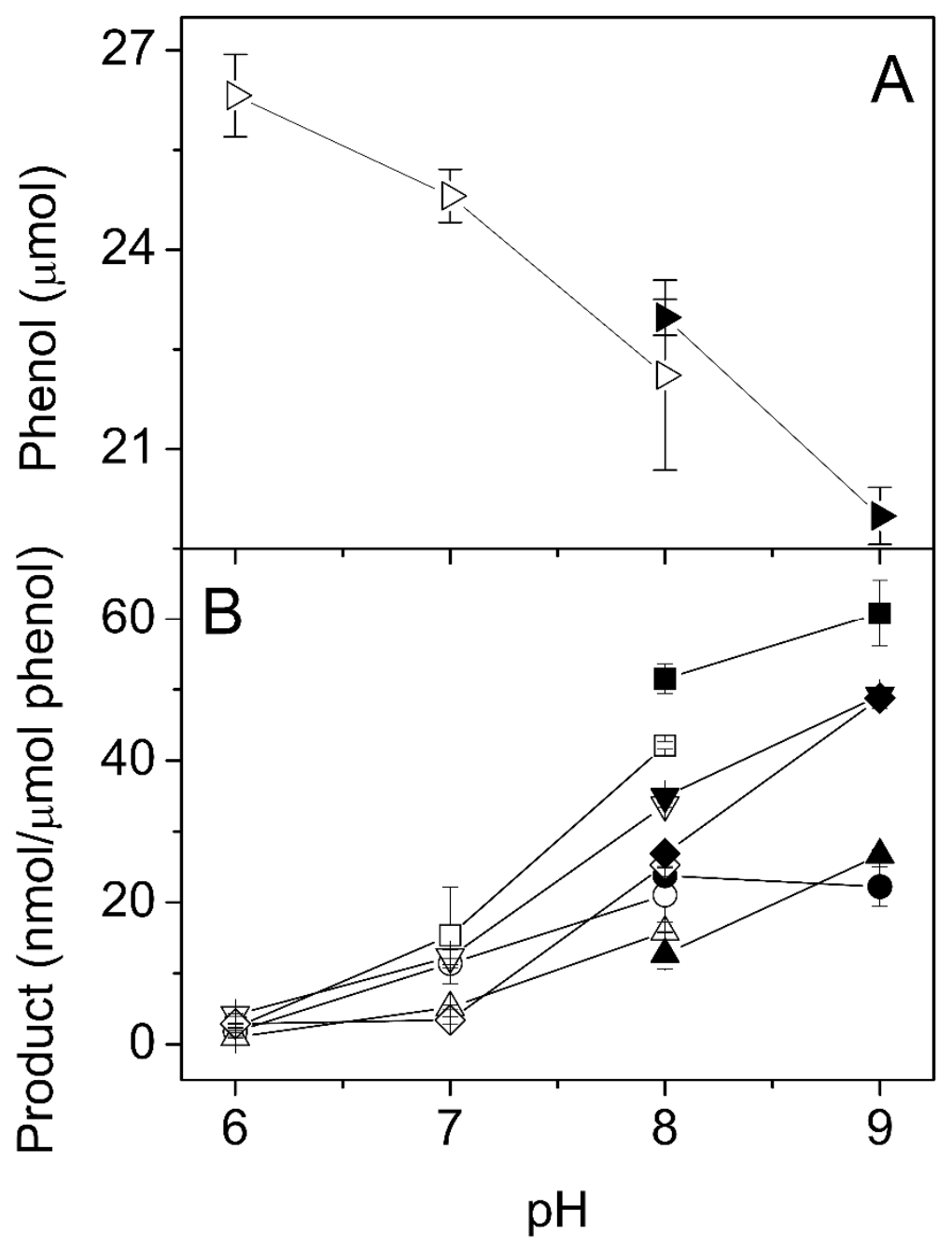

Figure 4 


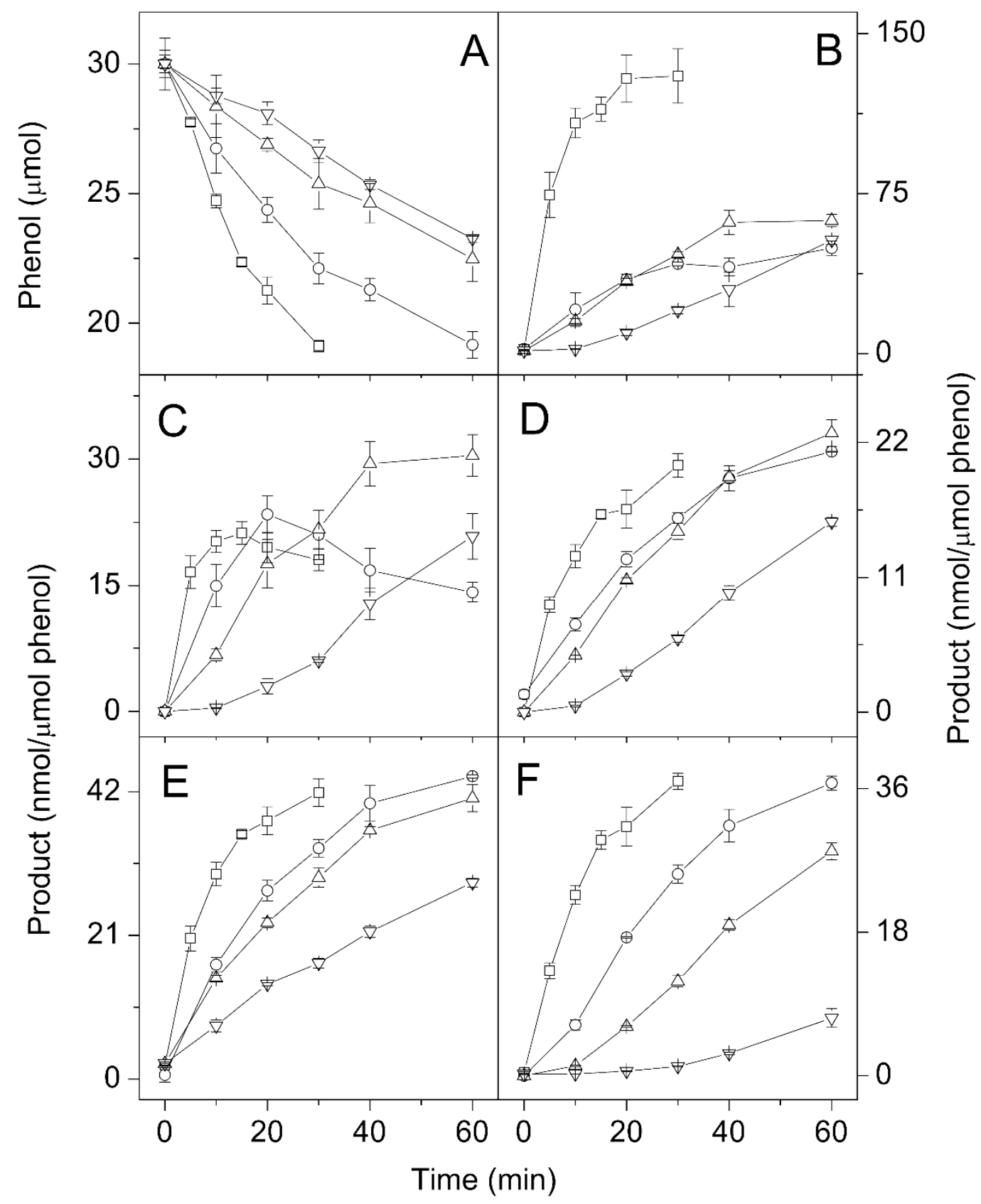

Figure 5 


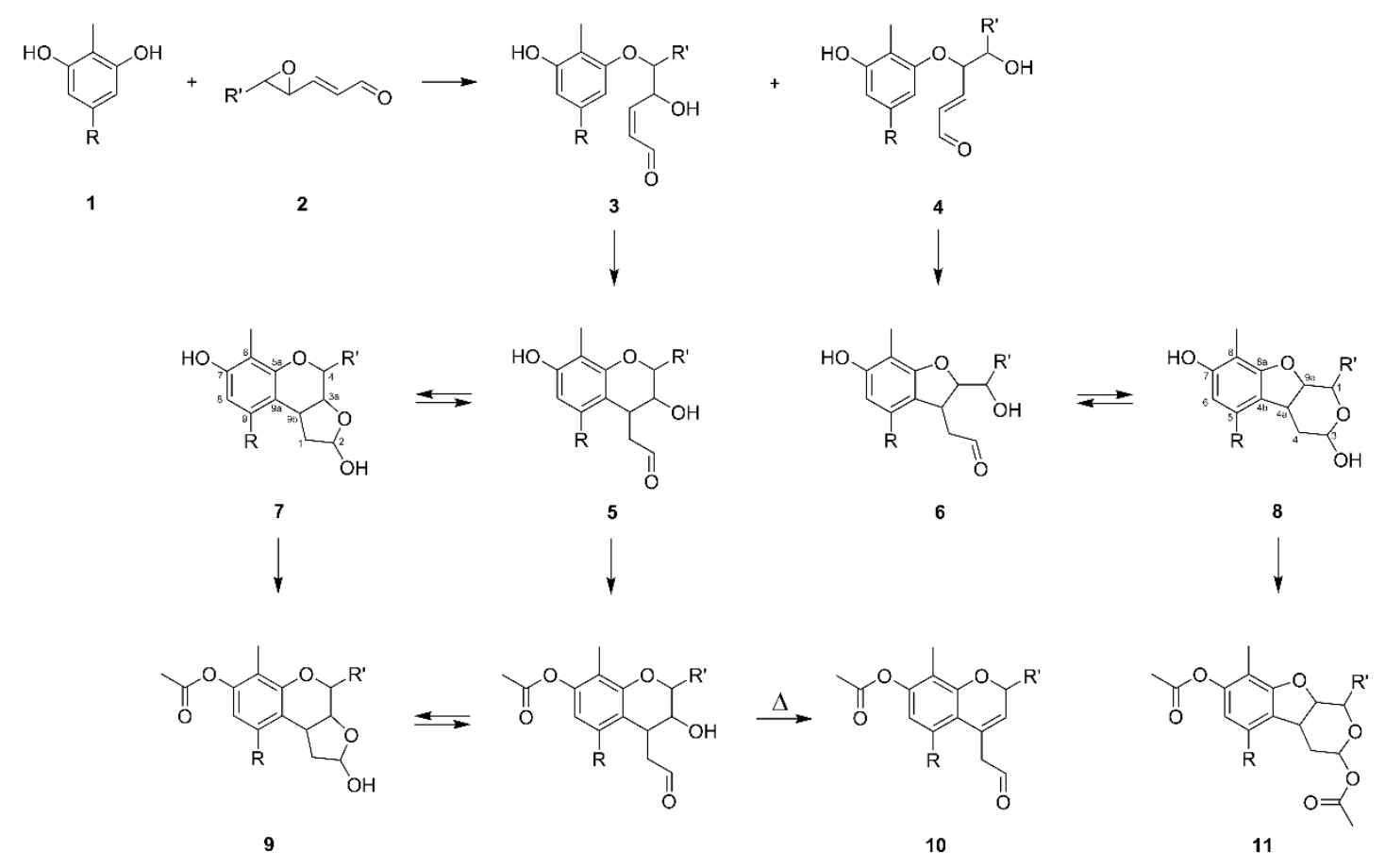

Figure 6 